\title{
DIFFERENTIAL EFFECTS OF AUXIN POLAR TRANSPORT INHIBITORS ON ROOTING IN SOME CRASSULACEAE SPECIES
}

\author{
${ }^{1}$ Marian Saniewski, ${ }^{1}$ Justyna Góraj, ${ }^{1}$ Elżbieta Węgrzynowicz-Lesiak, \\ ${ }^{2}$ Kensuke Miyamoto, ${ }^{3}$ Junichi Ueda
}

\author{
${ }^{1}$ Research Institute of Horticulture \\ Konstytucji 3 Maja 1/3, 96-100 Skierniewice, Poland \\ ${ }^{2}$ Faculty of Liberal Arts and Sciences, Osaka Prefecture University \\ 1-1 Gakuen-cho, Naka-ku, Sakai, Osaka 599-8531, Japan \\ ${ }^{3}$ Graduate School of Science, Osaka Prefecture University \\ 1-1 Gakuen-cho, Naka-ku, Sakai, Osaka 599-8531, Japan \\ e-mail: Marian.Saniewski@insad.pl
}

Received: 14.01.2014

\begin{abstract}
Effects of auxin polar transport inhibitors, 2,3,5-triiodobenzoic acid (TIBA), 1-N-naphthylphthalamic acid (NPA) and methyl 2-chloro-9-hydroxyfluorene-9-carboxylate (morphactin IT 3456), as a lanolin paste, on root formation in cuttings of some species of Crassulaceae, such as Bryophyllum daigremontianum, B. calycinum, Kalanchoe blossfeldiana and $K$. tubiflora, were studied. Cuttings of these plants were easily rooted in water without any treatment. TIBA and morphactin IT 3456 completely inhibited root formation in the cuttings of these plants but NPA did not when these inhibitors were applied around the stem below the leaves. When TIBA and morphactin were applied around the stem near the top, but leaves were present below the treatment, the root formation was observed in B. calycinum and $K$. blossfeldiana but in a smaller degree than in control cuttings. These results strongly suggest that endogenous auxin is required for root formation in cuttings of Crassulaceae plants. The differential mode of action of NPA is discussed together with its effect on auxin polar transport.
\end{abstract}

Key words: Bryophyllum daigremontianum, B. calycinum, cuttings, Kalanchoe blossfeldiana, K. tubiflora, rooting, auxin, 2,3,5-triiodobenzoic acid, 1- $N$-naphthylphthalamic acid, morphactin IT 3456

Abbreviations: IAA - indole-3-acetic acid, IBA - indole-3-butyric acid, NAA - naphthalene-3-acetic acid, TIBA - 2,3,5-triiodobenzoic acid, NPA - 1-N-naphthylphthalamic acid, morphactin IT 3456 - methyl 2-chloro-9-hydroxyfluorene-9-carboxylate, morphactin HFCA - 9-hydroxyfluorene-9-carboxylic acid

\section{INTRODUCTION}

Rooting in cuttings is a useful method to propagate plants easily. To promote rooting, many adventitious roots in cuttings are required. The process of adventitious root formation can be divided into three stages: root induction in which molecular and biochemical changes occur before any cytological event, root initiation when the first anatomical modifications take place, and protrusion, corresponding to the emergence of root primordial. Auxin indole-3-acetic acid (IAA) is one of essential endogenous hormones known to play the most important role in the formation of adventitious roots [1]. Exogenous auxins, IAA, indole-3-butyric acid (IBA) and naphthalene-3-acetic acid (NAA) are widely used in the promotion of rooting cuttings.

Auxin has been well known to play a crucial role in many aspects and development in plants [2]. Auxin moves from the shoot apex to the root tip between plant cells through a combination of membrane diffusion. Carrier- and/or facilitator-mediated transport has been shown to modulate both auxin biosynthesis and auxin movement $[3,4]$. The auxin polar transport generates auxin maxima and gradients within tissues that are instrumental in the diverse regulation of various plant developmental processes, including elongational growth, organogenesis, vascular tissue formation, embryogenesis, tropisms and many other processes, including root formation in cuttings as described above [4].

Compounds such as 1- $N$-naphthylphthalamic acid (NPA), 2,3,5-triiodobenzoic acid (TIBA), methyl 
2-chloro-9-hydroxyfluorene-9-carboxylate (morphactin IT 3456), and 9-hydroxyfluorene-9-carboxylic acid (morphactin HFCA) have been well known to be effective auxin polar transport inhibitors affecting many physiological and developmental processes in plants. Several studies have shown the inhibition of rooting and inhibition of auxin transport in many plants $(\mathrm{Cu}$ cumis sativus, Helianthus annuus, Dianthus caryophyllus, Salix tetrasperma, Vigna radiata, Pisum sativum, Forsythia $x$ intermedia, Syringa vulgaris) after application of NPA and TIBA [5-10]. Morphactin IT 3456 also inhibited adventitious root formation in cuttings of Pisum sativum [11], hypocotyl cuttings of Impatiens balsamina [12] and stem cuttings of Salix tetrasperma [13]. The plantlet root emergence from epiphyllous plantlets on excised leaves of Bryophyllum marnierianum was completely inhibited by TIBA, but shoot growth was not significantly inhibited by TIBA, whereas NPA had almost no effect on plantlet root development on leaves [14]. However, adventitious root growth in cuttings of Bryophyllum marnierianum was inhibited both by TIBA and NPA when cuttings were incubated with their basal ends in the presence of these compounds [14]. These results suggest that the effects of auxin polar transport inhibitors depend on plant species and/or its growth situation. Auxin transport inhibitors interfere with basipetal polar transport of auxin and in this way change auxin distribution, resulting in perturbations in plant development. Generally, various effects of auxin transport inhibitors have been proposed to be caused, at molecular level, by interference with the auxin-efflux carrier and/or facilitator, but the detailed mechanism remains unclear whether or how blockage of the efflux of auxin by the inhibitors is involved in the effects of these inhibitors on physiological and developmental processes in plants [15].

Recently we have found differential effects of auxin polar transport inhibitors on rooting in cuttings of some Crassulaceae plants. Here, we report the differential effects of auxin polar transport inhibitors, TIBA, NPA and morphactin IT 3456, on root formation in cuttings of Bryophyllum daigremontianum, $B$. calycinum, Kalanchoe blossfeldiana, and K. tubiflora. The differential mode of action of NPA compared to that of TIBA and morphactin IT 3456 is intensively discussed focusing on their mode of inhibitory action on auxin polar transport as well.

\section{MATERIALS AND METHODS}

Young cuttings of some Crassulaceae species, Bryophyllum daigremontianum, Bryophyllum calyci- num, Kalanchoe blossfeldiana and Kalanchoe tubiflo$r a$, were prepared and subjected to rooting in distilled water in natural light conditions in a greenhouse with shading, if necessary. Cuttings with a length of $8-9 \mathrm{~cm}$ were kept separately in $100 \mathrm{ml}$ Erlenmeyer flasks with change of water every 3 days. Auxin transport inhibitors, TIBA, NPA and morphactin IT 3456, at concentrations of $0.2 \%(\mathrm{w} / \mathrm{w})$ and sometimes $0.5 \%(\mathrm{w} / \mathrm{w})$ in lanolin paste, were applied as a ring around the lower side of the stem under all leaves of the cutting, or a ring around the upper side of the stem near the top of cuttings. The experiments were carried out in different seasons in the year, mainly on January 23, July 28 and September 1 or 5 .

Rooting was visually observed every day after starting the experiments and the number of initiated roots was calculated. Based on the observations, the effects of the chemicals were evaluated. Ten cuttings were used for each treatment and the experiments were repeated 3 to 5 times. TIBA, NPA and morphactin IT 3456, purchased from Aldrich, Trade TCI Mark and Celamerck GmbH and Co. KG, Germany, respectively, were used without any further purification.

\section{RESULTS}

Young cuttings of all these species, Bryophyllum daigremontianum, Bryophyllum calycinum, Kalanchoe blossfeldiana and Kalanchoe tubiflora, were easily rooted in water without any additional treatment and sprouting of roots was visible in about one week (Fig. 1). The main sprouted roots formed many lateral roots (Fig. 1). TIBA and morphactin IT 3456 completely inhibited root formation in cuttings of these plants when these inhibitors were applied as a ring around the lower side of the stem under all leaves of the cutting (Fig. 1, Table 1). When TIBA and morphactin were applied as a ring around the upper side of the stem near the top of cuttings, root formation was observed in cuttings of B. calycinum and $K$. blossfeldiana, but to a much smaller extent as compared to that in control cuttings (Fig. 2, Table 2). Cuttings of B. tubiflora and $B$. daigremontianum were not used in this kind of experiment. On the other hand, NPA did not inhibit rooting in cuttings of $B$. daigremontianum, $B$. calycinum, K. blossfeldiana and $K$. tubiflora when NPA was applied using the two methods described above (Figs. 1 and 2, Tables 1 and 2). These results strongly suggest that endogenous auxin produced and/or restored in the regions below the treatments of TIBA and morphactin and also NPA is required for root formation in cuttings. 


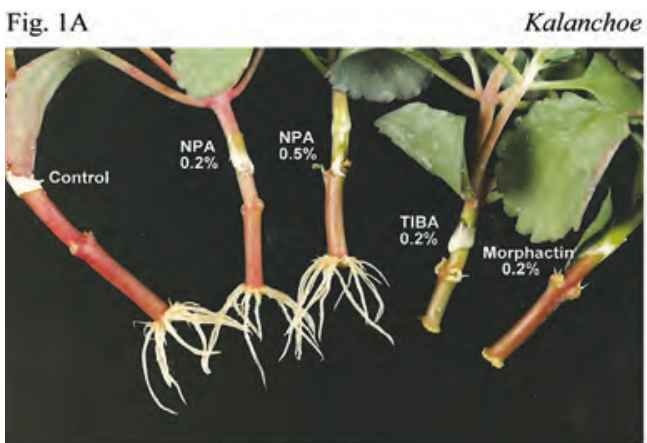

Treatment: July 28

Photographed: August 08

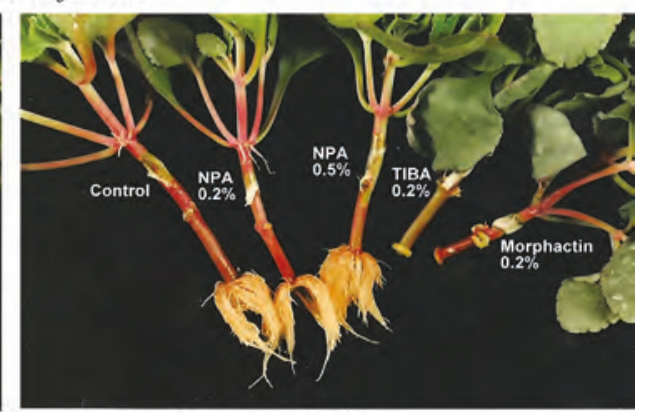

Treatment: July 28

Photographed: September 03

Fig. 1B

Bryophyllum daigremontianum

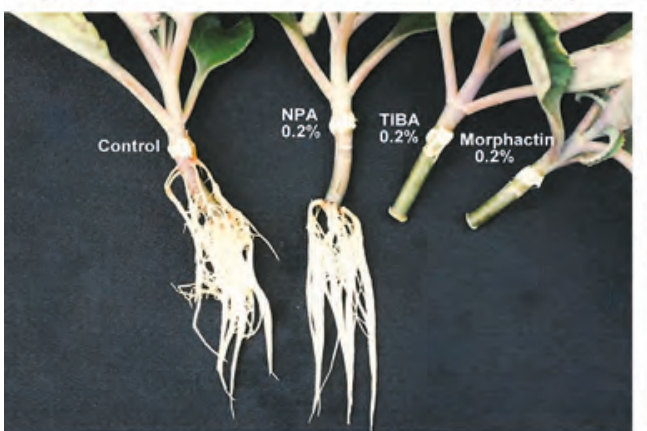

Treatment: July 28

Photographed: August 08

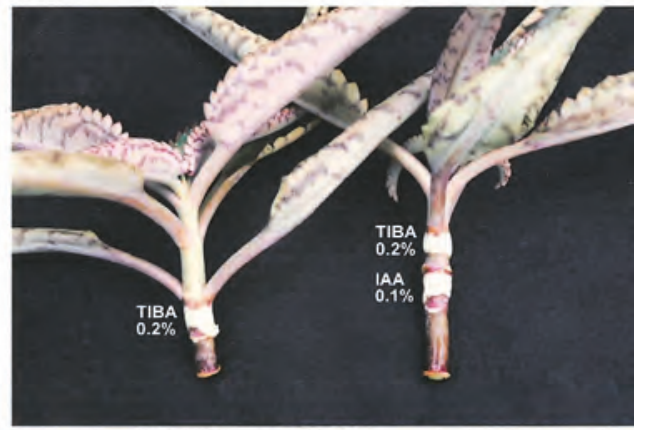

Treatment: July 28

Photographed: September 03

Fig. 1C

Kalanchoe tubiflora

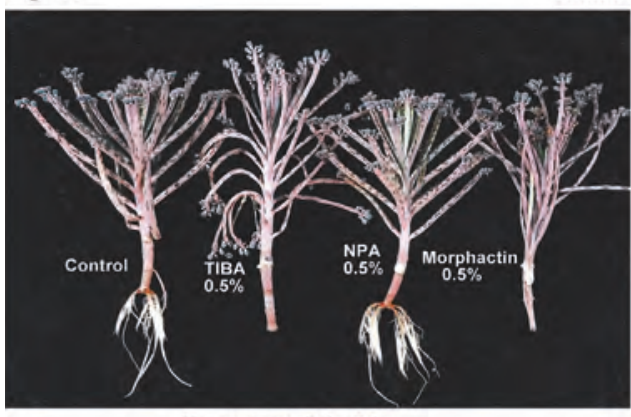

Treatment: July 28

Photographed: August 08

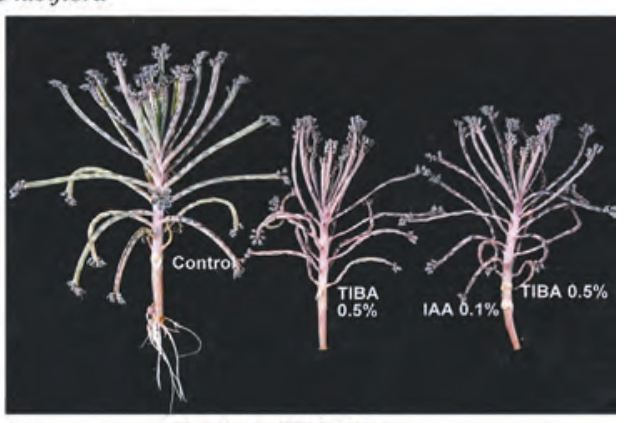

Treatment: July 28

Photographed: September 03

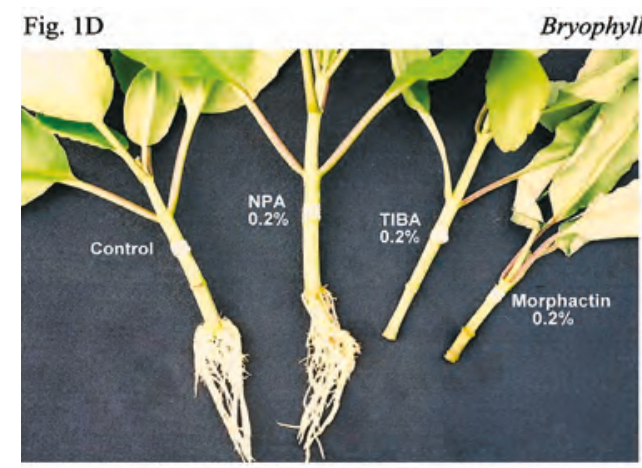

Treatment: September 01 Photographed: September 24

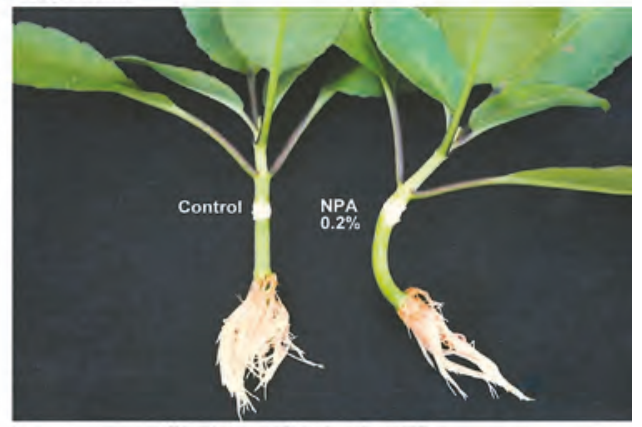

Treatment: September 05

Photographed: September 30

Fig. 1. The effect of TIBA, morphactin IT 3456 and NPA on rooting in some Crassulaceae species, (A) Kalanchoe blossfeldiana, (B) Bryophyllum daigremontianum, (C) Kalanchoe tubiflora and (D) Bryophyllum calycinum. TIBA, NPA and morphactin were used at concentrations of 0.2 and $0.5 \%(\mathrm{w} / \mathrm{w})$ in lanolin paste and applied as a ring around the stem under the shoot with leaves.

TIBA and morphactin completely inhibited root formation but NPA did not. 

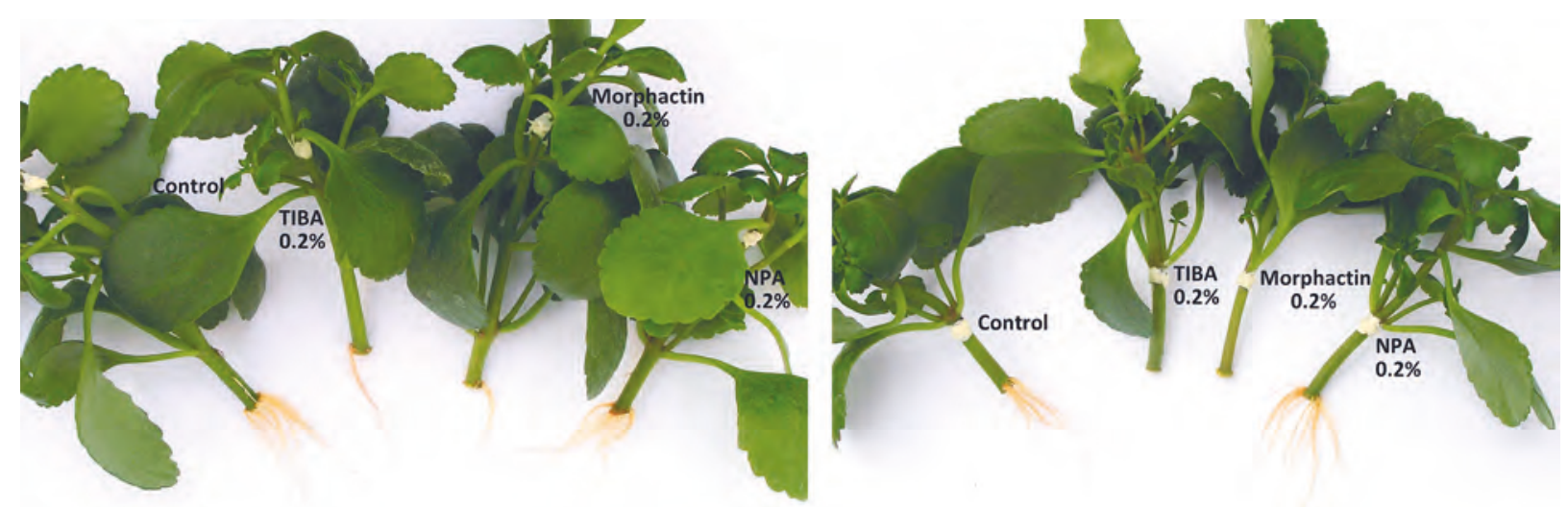

Fig. 2. The effect of TIBA, morphactin IT 3456 and NPA on rooting of cuttings of Kalanchoe blossfeldiana; treatments made on September 19, photographed on October 15

left - treatments around the stem as a ring under the shoot with leaves

right - treatments around the stem as a ring near the apex with leaves present below the treatment

Table 1

The effect of TIBA, NPA and morphactin IT 3456 applied in lanolin paste around the stem below leaves on root formation in cuttings of some Crassulaceae species. Measurements of number of roots were made 10 days after treatment

\begin{tabular}{|c|c|c|c|c|c|c|c|c|}
\hline \multirow{3}{*}{ Species } & \multirow{3}{*}{$\begin{array}{c}\text { Date of } \\
\text { treatment }\end{array}$} & \multicolumn{7}{|c|}{ Average number of roots/plant } \\
\hline & & \multirow[t]{2}{*}{ Control } & \multicolumn{2}{|c|}{ TIBA } & \multicolumn{2}{|c|}{ NPA } & \multicolumn{2}{|c|}{ Morphactin } \\
\hline & & & $0.2 \%$ & $0.5 \%$ & $0.2 \%$ & $0.5 \%$ & $0.2 \%$ & $0.5 \%$ \\
\hline K. blossfeldiana & July 28 & 11 & 0 & 0 & 10 & 10 & 0 & 0 \\
\hline B. daigremontianum & July 28 & 9 & 0 & - & 10 & - & 0 & - \\
\hline K. tubiflora & July 28 & 11 & 0 & 0 & 8 & 8 & 0 & 0 \\
\hline B. calycinum & Sept. 01 & 13 & 0 & - & 12 & - & 0 & - \\
\hline
\end{tabular}

Table 2

The effect of TIBA, morphactin IT 3456 and NPA applied in lanolin paste around the stem below the leaves and when applied near the top of the stem with leaves present below the treatment on root formation in cuttings of Kalanchoe blossfeldiana; treatments made on September 19, measurements of number of roots on October 15

\begin{tabular}{|c|c|c|c|c|}
\hline \multirow{2}{*}{$\begin{array}{l}\text { Treatment } \\
\text { around the stem as a ring }\end{array}$} & \multicolumn{4}{|c|}{ Number of roots/plant } \\
\hline & Control & TIBA $0.2 \%$ & NPA $0.2 \%$ & Morphactin $0.2 \%$ \\
\hline below leaves & 12 & 0 & 11 & 0 \\
\hline $\begin{array}{l}\text { near the top stem, leaves present } \\
\text { below the treatment }\end{array}$ & 10 & 3 & 10 & 2 \\
\hline
\end{tabular}

\section{DISCUSSION}

The results of this study gave rise to an important question why NPA does not inhibit rooting in cuttings of some Crassulaceae plants. Similar observations have been reported in epiphyllous plantlets of Bryophyllum marnierianum [14] but the mode of actions of NPA has not been clear yet. NPA has been well known as a potent inhibitor of auxin polar trans- port. Other chemicals, TIBA and morphactin IT 3456, have a similar function as that of NPA: they substantially inhibit rooting. NPA has been known to inhibit auxin polar transport in dicotyledons and monocotyledons by inhibiting active auxin secretion [16]. NPA inhibited auxin transport by specifically binding to the auxin efflux carrier [17]. The endogenous auxin, IAA, did not compete with NPA for the binding site [18] but the NPA-binding site was important for auxin 
transport [19]. These results indicate that NPA inhibits IAA transport by specific binding to the so-called NPA receptors, thereby blocking the carrier- and/or facilitator-mediated efflux of IAA [20]. A h k a mi et al. [21], using NPA as an auxin transport blocker, showed that spontaneous root formation in leafy cuttings of Petunia hybrida is dependent on auxin homeostasis induced by auxin polar transport in the rooting zone. $\mathrm{R}$ in c o n et al. [22] also compared the effects of auxin transport inhibitors, TIBA and NPA, on rhizogenesis and mycorrhizal establishment of spruce (Picea abies) seedlings inoculated with Laccaria bicolor. The ectomycorrhizal fungus Laccaria bicolor, which can synthesize IAA in pure culture, stimulated lateral root formation on spruce seedlings and the colonization of the top-root cortex by the fungus. Exogenously applied IAA also stimulated lateral root formation in spruce seedlings but to a lesser degree than Laccaria bicolor. It was shown that TIBA completely inhibited the stimulatory effect of Laccaria bicolor on lateral root formation on spruce seedlings, but NPA inhibited it only partially. Thein and Michalke [23] also showed that bisulfite interacted with the binding sites of NPA, and its inhibition was non-competitive. Bisulfite at 2 or $3 \times 10^{-5} \mathrm{M}$ reduced NPA binding to $50 \%$ of the control for membrane-bound and solubilized binding sites, respectively. Bisulfite has also been known to inhibit flavoprotein oxidases and a few other enzymes such as ribulose-1,5-diphosphate carboxylase, catalase, and peroxidases (cited by The in and M i chalke [23]). Judging from these observations together with the results in this study, TIBA, morphactin and NPA might interact with different proteins, respectively, and specifically interfere with facilitators of auxin polar transport. In addition, NPA might not be able to abolish or disturb such auxin homeostasis in some Crassulaceae species.

NPA has been reported to be a potent inhibitor of light-grown hypocotyl elongation, whereas in the dark it has no significant effect on hypocotyl growth of sunflower (Helianthus annuus) and marrow (Cucurbita pepo) seedlings [24] as well as Arabidopsis thaliana seedlings [25-27]. Murphy and Taiz [26,27] demonstrated that NPA is hydrolyzed by NPA amidase at the root-hypocotyl transition zone and other regions of Arabidopsis thaliana seedlings to $\alpha$-naphthylamine $(\alpha \mathrm{NA})$, and then $\alpha \mathrm{NA}$ combines to form 1,1'-azonaphthylene (ANA), which aggregates to yield an insoluble precipitate. The enzyme producing $\alpha$ NA from NPA is mostly likely arylamidase [26]. NPA amidase activity was detected in plasma membrane-enriched fractions obtained from Arabidopsis seedlings. The NPA-induced growth inhibition of Arabidopsis thaliana seedlings was strongly promoted by blue light [26,27]. J e n s e n et al. [25] and Murphy and Taiz [26,27] showed that blue light wavelengths were also the most effective for the NPA-staining reaction caused by the degradation of NPA and the formation of $\alpha$ NA and ANA by NPA amidase and that the NPA amidase activity was inhibited by phloretin, genestein, curcumin, quercitin, bestatin and EDTA. It is possible that the amidase responsible for the NPA staining reaction either binds NPA or regulates NPA binding. The lack of inhibition of root formation in some Crassulaceae species might be caused by the lack of NPA degradation by NPA amidase to other constituents as described above.

\section{CONCLUSIONS}

1. Auxin polar transport inhibitors, 2,3,5-triiodobenzoic acid (TIBA) and methyl 2-chloro-9-hydroxyfluorene-9-carboxylate (morphactin IT 3456), completely inhibited root formation in cuttings of Bryophyllum daigremontianum, B. calycinum, $\mathrm{Ka}$ lanchoe blosfeldiana and $K$. tubiflora (Crassulaceae), but 1- $N$-naphthylphthalamic acid (NPA) did not affect rooting of these species when these inhibitors were applied as a lanolin paste at a concentration of $0.2 \%$ around the stem below the leaves.

2. The application of TIBA, NPA and morphactin IT 3456 in B. calycinum and K. blossfeldiana around the stem near the top of the stem with leaves present below the treatments caused TIBA and morphactin IT 3456 to inhibit root formation only partially and again NPA did not affect root formation (the experiment was not performed on $B$. daigremontianum and $K$. tubiflora).

3. Based on these results, it is concluded that endogenous auxin transport from leaves is required for root formation in cuttings of some species of Crassulaceae, and the process is totally inhibited by TIBA and morphactin IT 3456 but not by NPA.

4. To clarify the differential mode of action of NPA in rooting of cuttings in some Crassulaceae plants compared to that of TIBA and morphactin IT 3456, further intensive studies focusing on the molecular aspects of the mode of action of NPA will be required in the near future.

\section{Acknowledgments}

The research was supported by the Ministry of Science and Higher Education of Poland as part of the statutory activities (7.2.1) of the Department of General and Molecular Biology, Research Institute of Horticulture in Skierniewice

\section{Authors' contributions}

The following declarations about authors' contributions to the research have been made: designing 
the experiments: MS, JU; field work: JG, EW-L, JU; writing of the manuscript: MS, KM, JU.

\section{REFERENCES}

1. Han H, Zhang S, Sun X. A review on the molecular mechanism of plant rooting modulated by auxin. Afr J Biotechnol. 2009; 8: 348-353.

2. Berleth T, Sachs T. Plant morphogenesis: long-distance coordination and local pattering. Curr Opin Plant Biol. 2001; 4: 57-62. http://dx.doi.org/10.1016/S1369-5266 (00)00136-9

3. Kramer EM, Bennet t MJ. Auxin transport: a field in flux. Trends Plant Sci. 2006; 11: 382-386. http://dx.doi. org/10.1016/j.tplants.2006.06.002

4. Roberts HS, Friml J. Auxin and other signals on the move in plants. Nature Chemical Biology. 2009; 5: 325-332.

5. Katsumi M, Chiba Y, Fukuyama M. The role of the cotyledons and auxin in the adventitious root formation of hypocotyl cuttings of light-grown cucumber seedlings. Physiol Plant. 1969; 22: 993-1000. http://dx.doi. org/10.1111/j.1399-3054.1969.tb07457.x

6. Batten DJ, Goodwin PB. Auxin transport inhibitors and the rooting of hypocotyl cuttings from etiolated mung-bean Vigna radiata (L.) Wilczek seedlings. Ann Bot. 1981; 47: 497-503.

7. Liu JH, Reid DM. Adventitious rooting in hypocotyls of sunflower (Helianthus annuus) seedlings. IV. The role of changes in endogenous free and conjugated indole-3-acetic acid. Physiol Plant. 1992; 86: 285-292.

8. Guerrero JR, Garrido G, Acosta M, Sánchez-Bravo J. Influence of 2,3,5 triiodobenzoic acid and 1-naphthylphthalamic acid on indoleacetic acid transport in carnation cuttings: relationship with rooting. J Plant Growth Regul. 1999; 18: 183-190. http://dx.doi.org/10.1007/ PL00007068

9. Garrido G, Guerrero JR, Cano EA, Acosta M, Sánchez-Bravo J. Origin and basipetal of the IAA responsible for rooting and carnation cuttings. Physiol Plant. 2002; 114: 303-312. http://dx.doi.org/10.1034/j.1399-3054.2002.1140217.x

10. Marks TR, Ford Y-Y, Cameron RWF, Goodwin C, Meyers PE, Judd HL. A role for polar auxin transport in rhizogenesis. Plant Cell Tiss Organ Cult. 2002; 70: 189-198.

11. Khan AR, Andersen AS, Hansen J. Morphactin and adventitious root formation in pea cuttings. Physiol Plant. 1977; 39: 97-100. http://dx.doi.org/10.1111/ j.1399-3054.1977.tb04016.x

12. Nanda KK, Bhattacharya NC, Kaur NP. Effect of morphactin on peroxidases and its relationship to rooting hypocotyl cuttings of Impatiens balsamina. Plant Cell Physiol. 1973; 14: 207-211.

13. Kochhar VK, Anand VK, Nanda KK. Effect of morphactin on rooting and sprouting of buds on stem cuttings of Salix tetrasperma. Bot Gaz. 1972; 133: 361-368. http://dx.doi.org/10.1086/336656
14. Kulka RG. Hormonal control of root development on epiphyllous plantlets of Bryophyllum (Kalanchoe) marnierianum; role of auxin and ethylene. J Exp Bot. 2008; 59: 2361-2370. http://dx.doi.org/10.1093/jxb/ern106

15. Fujita H, Syono K. Genetic analysis of the effects of polar auxin transport inhibitors on root growth in Arabidopsis thaliana. Plant Cell Physiol. 1996; 37: 1094-1101. http://dx.doi.org/10.1093/oxfordjournals.pcp.a029059

16. Depta H, Eisele KH, Hertel R. Specific inhibitors of auxin transport: action on tissue segments and in vitro binding to membranes from maize coleoptiles. Plant Sci Letters. 1983; 31: 181-192. http://dx.doi.org/10.1016/0304-42 11(83)90055-X

17. Katekar GF, Giessler AE. Auxin transport inhibitors. IV. Evidence of a common mode of action for a proposed class of auxin transport inhibitors: The phytotropins. Plant Physiol. 1980; 66: 1190-1195. http://dx.doi.org/10.1104/ pp.66.6.1190

18. Lomax TL, Muday GK, Rubery PH. Auxin transport. In: Plant hormones, ed. by P.J. Davis. Kluwer Academic Publishers, Dordrecht, The Netherlands, 1995; pp. 509-530.

19. Ruegger M, Dewey E, Hobbie L, Brown D, Bernasconi P, Turner J, Muday G, Estelle M. Reduced naphthylphtalamic acid binding in the tir3 mutant of Arabidopsis is associated with a reduction in polar transport and diverse morphological defects. Plant Cell. 1997; 9: 745-757.

20. Muday GK, Brunn SA, Haworth P, Subramanian M. Evidence for a single naphthylphthalamic acid binding site on the zucchini plasma membrane. Plant Physiol. 1993; 103: 449-456.

21. Ahkami AH, Melzer M, Ghaffari MR, Pollmann S, Javid MG, Shahinnia F, Hajirezaei MR, Druege U. Distribution of indole-3-acetic acid in Petunia hybrida shoot tip cuttings and relationship between auxin transport, carbohydrate metabolism and adventitious root formation. Planta. 2013;238:499-517.http://dx.doi.org/ 10.1007/s00425-013-1907-z

22. Rincon A, Priha O, Sotta B, Bonnet M, Le Tac on F. Comparative effects of auxin transport inhibitors on rhizogenesis and mycorrhizal establishment of spruce seedlings inoculated with Laccaria bicolor. Tree Physiol. 2003; 23: 785-791. http://dx.doi.org/10.1093/treephys/23.11.785

23. Thein M, Michalke W. Bisulfite interacts with binding sites of the auxin-transport inhibitor N-1-naphthylphthalamic acid. Planta. 1988; 176: 343-350. http://dx.doi.org/ 10.1007/BF00395414

24. Tamimi S, Firn RD. The basipetal auxin transport system and the control of cell elongation in hypocotyls. J Exp Bot. 1985; 36: 955-962. http://dx.doi.org/10.1093/ jxb/36.6.955

25. Jensen PJ, Hangarter RP, Estelle M. Auxin transport is required for hypocotyl elongation in light-grown but not dark-grown Arabidopsis. Plant Physiol. 1998; 116: 455-462. http://dx.doi.org/10.1104/pp.116.2.455 
26. Murphy A, Taiz L. Naphthylphthalamic acid is enzymatically hydrolyzed at the hypocotyl-root transition zone and other tissues of Arabidopsis thaliana seedlings. Plant Physiol Biochem. 1999a; 37: 413-430.

27. Murphy A, Taiz L. Localization and characterization of soluble and plasma membrane aminopeptidase activities in Arabidopsis thaliana seedlings. Plant Physiol Biochem. 1999b; 37: 431-443.

\section{Zróżnicowany wpływ inhibitorów polarnego transportu auksyny na ukorzenianie niektórych gatunków z rodziny Crassulaceae}

\section{Streszczenie}

Badano wpływ inhibitorów polarnego transportu auksyny, kwasu 2,3,5-trójjodobenzoesowego (TIBA), kwasu 1- $N$-naftyloftalamowego (NPA) i morfaktyny, kwasu metylo 2-chloro-9-hydroksy-fluoreno-karboksylowego (IT 3456), na tworzenie korzeni w sadzonkach niektórych gatunków Crassulaceae, Brophyllum daigremontianum, B. calycinum, Kalanchoe blossfeldiana i $K$. tubiflora. Sadzonki tych gatunków łatwo się ukorzeniają w wodzie bez dodatkowego traktowania. Stwierdzono, że TIBA i morfaktyna całkowicie hamują tworzenie się korzeni, kiedy inhibitory były zastosowane w paście lanolinowej na łodydze poniżej liści. Kiedy TIBA i morfaktynę u B. calycinum i K. blossfeldiana podano wokół łodygi przy wierzchołku, a liście na łodydze były poniżej traktowania, korzenie tworzyły się ale w mniejszym stopniu niż w roślinach nietraktowanych. Otrzymane wyniki sugerują, że endogenna auksyna jest niezbędna dla tworzenia się korzeni w sadzonkach roślin z rodziny Crassulaceae. Zróżnicowane działanie NPA w porównaniu z TIBA i morfaktyną na ukorzenianie jest dyskutowane $\mathrm{z}$ różnym wpływem oddziaływania NPA na polarny transport auksyny.

Handling Editor: Elżbieta Pogroszewska

This is an Open Access digital version of the article distributed under the terms of the Creative Commons Attribution 3.0 License (creativecommons.org/licenses/by/3.0/), which permits redistribution, commercial and non-commercial, provided that the article is properly cited. 